\title{
Information and Communication Technologies and Development of Learners' Critical Thinking: Primary School Teachers' Attitudes
}

\author{
Panagiotis Giavrimis \\ Lecturer, Department of Sociology, University of the Aegean, Greece \\ Pamfilis 17, 81100 Mytilene-Lesvos, Greece \\ Tel: 30-22510-36554Ｅ-mail: giavrimis@soc.aegean.gr \\ Efstratios Papanis \\ Assistant Professor, Department of Sociology, University of the Aegean, Greece \\ Theofilou Hatzimichael 5, 81100 Mytilene-Lesvos, Greece \\ Tel: 30-22510-36520Ｅ-mail: papanis@papanis.com
}

Eirini-Myrsini Papanis

Med, Phd Student, Department of Educational and Social Policy

University of Macedonia, Greece

Parou 11, 81100 Mytilene-Lesvos, Greece

Tel: 30-22511-00283Ｅ-mail: myrena@gmail.com

Received: August 9, 2010 Accepted: March 7, 2011 doi:10.5539/ies.v4n3p150

\begin{abstract}
The Information and Communication Technologies exercise a great impact on the ways people work, communicate and interact, and contribute considerably to the development of learners' skills. However, the use of Information and Communication Technologies cannot lead to the development of high-order skills and of critical thinking, if not combined with the appropriate teaching methods.

In the light of the above, the aim of the present research is to identify and record Primary School teachers' beliefs about the impact of Information and Communication Technologies on the enhancement of critical thinking. An analysis of the skills taught within the Greek educational context and considered to be necessary for the development of critical thinking, is also provided. The data elicitation tool is a questionnaire devised for the needs of the specific research and the sample is comprised by 118 Primary School teachers working on the Greek island of Lesvos.
\end{abstract}

Keywords: Information and Communication Technology (ICT), Critical thinking, Digital environment

\section{Introduction}

One of the basic differences between traditional and technology-based education is the emphasis given by the latter on various multi-sensory presentations in teaching and the rejection of older behavioural approaches and methods. Computers are becoming even more user-friendly, exploiting new modes of codification and sophisticated technologies, transferring data based on sound, image, and hypertext and forming conditions of a virtual reality. Software ceases to be situated on the end users devices and is being provided through the Internet itself (Giavrimis, Papanis \& Roumeliotou, 2009). Texts are becoming dynamic, capable of modification by a plethora of users at the same time and notions, like 'social mechanisms' and 'network communities' have now become a reality. Unfortunately, the developers of educational policies often realize the great potential of technologies when those have already become passé. Moreover, and surprisingly enough, the use of the internet has not yet become a broadly followed practice into the Greek educational context. If such paradoxes are overcome, the computer-based learning 
and the teaching methods, which should permit the sensory-motor, the visual and the symbolic representation of knowledge (Bruner, 1996), will be supported and reinforced.

The above mentioned requirements regarding the representation of knowledge, was the "Achilles tendon" of the traditional teaching methodologies. Learners used to be passive receivers of knowledge, as they were rarely given the opportunity for autonomous and self-directed learning (Trilianos, 2000). The gradual rejection of outdated teaching methods and the establishment of new pedagogical motives contributed to acquiring knowledge through a dynamic and active modification of its structures (Kapsalis \& Nima, 2002).

In computer-based education the learner gets constant feedback, takes decisions concerning the frequency, the difficulty level and the type of the cognitive stimuli he/she wishes to receive, and is an active participant in internet communities. In other words, he/she has control over the learning process. The post-industrial models of learning aim at the development of metacognition, instead of the mere acquisition of knowledge. The material constraints are eliminated and the variety of information sources becomes even broader, while at the same time opportunities are provided for the simulation of financial, biological, social, etc, systems for educational purposes (Crawford, 1996). The teacher advises and consults rather than directs the learners, and, via the educational software available in relevant internet sites, can select the most appropriate teaching methods, assign and check research designs and give feedback concurrently to many learners (Papert, 1980, 1996).

The shift towards the application of structural educational models assisted in viewing learning as the result of learners' self-activation, in order to construct and develop their cognitive structures, or even modify, if necessary, the already existed ones (Koliadis, 1995; Margolin, 1997). The role of the computer and the internet in education is remarkable, since they link data bases, institutions, libraries and individuals. They, also, ensure a continuous flow of information and inculcate new educational habits and standards. Depending on the type of the provided feedback, the digital environment can offer positive reinforcement and motivation, causing feelings of gratification, relaxation and confidence, or can lead to disappointment, surprise or inconvenience. Thus, the interaction becomes "natural" and is in tune with learners' idiosyncrasy, temperament and needs (Papert, 1996). The digital environment includes responding to questionnaires, learners' assessment and constant provision of feedback, subject selection from a vast range of hyperlinks, and participation in group discussions on various topics. Moreover, it provides opportunities for the publication of "book marks", related to hypertexts and links of special interest, the investigation of terms, through the use of key-words, the modification of the teaching material according to the learner's needs, the storage of important texts, the publication of "personal" teaching material, the search of relative texts, lesson plans, simulations of economic models, biological systems and electronic categories, the conduction of experiments, visits to virtual museums, etc. Students can also interact with their teachers much faster and more often, either individually or in groups, at the same time or not, whilst the teacher assumes the role of the mentor, giving directions and facilitating the learning process, as he/she would do in the case of classroom projects. Thus, cooperative learning is encouraged (Griffin \& Cole, 1984; Wertsch, 1984).

Researches on the effects of ICT on students' academic performance give evidence about the beneficial impact it exercises on learners' attainment of high levels of cognition (Trucano, 2005). What is even more interesting, though, is its contribution to the enhancement of higher order skills, such as critical thinking.

The demands of our post-modern era call for the development of critical thinking and of metacognitive skills that will lead to a qualitatively improved basic and vocational education (OECD, 1996) and will support young people to effectively respond to the demands of a globalized environment (Rifkin, 1996). Nowadays, learners should be taught how to think rather what to think. The international literature provides a variety of definitions and interpretations of critical thinking, since it is by itself a contextual construct. It is often defined as the skills a learner should possess, in order to act autonomously, to be able to evaluate information and data, to define specific aims and to select appropriate methodology of action (Hargreaves, 1999. Matsaggouras, 2004). For Tsui (2002:743), critical thinking is "an ability to identify issues and assumptions, recognize important relationships, make correct inferences, evaluate evidence or authority and deduce conclusions". According to Torff (2006:37), critical thinking is "a set of cognitive skills and strategies that increase the likelihood of a desired outcome". Obviously, critical thinking is a general concept, which encompasses a variety of skills. For Kahane (1997) critical thinking refers to 'argument analysis', for Mayer (1992) to 'problem solving', while according to Dawes (1988), critical thinking is the skill of 'decision making'. They all, agree, however, that these skills can be taught and cultivated in order to be used whenever necessary consciously and appropriately.

Unfortunately, instructions on critical thinking are not, at least most of the times, integrated in teaching and the Greek classroom remains rather traditional, engaging students in surface learning instead of deep. Thus, the learners 
often have to reproduce information and to memorise, at the moment that deeper learning, which creates critical thinkers, requires analysis of data, evaluation, testing of hypotheses, problem solving, planning and reflecting.

Technologies, thanks to their great potential and motivational character, energise the learners to gain control over their learning, to interact, to engage in complex mental situations and efforts. The results of researches concerning the impact of ICT on the enhancement of critical thinking indicate statistically significant correlations between studying within a technology-rich environment and the possession of critical thinking skills (Lee, 2002). McMahon (2009) found that the students who had been using ICT for more than five years possessed more critical thinking skills in comparison to those who had been using it for less than five years.

The wealth of resources available on internet develops inquiry skills, provides access to the world of knowledge and requires learners' critical thinking, in order to decide which information to accept and absorb and which to reject.

The visual nature of many educational technologies, the simulations and the animations contribute to in depth conceptual understanding, as they facilitate the creation of cognitive representations of difficult or unfamiliar to the learners notions and concepts (Passey at al., 2004; Livingston \& Condie, 2003). Thus, having comprehended completely a new concept, the learner can think of it critically, forming personal representations. Simulations, in particular, are considerably useful for the understanding of difficult-to-grasp scientific principles and relationships, while animations, according to Cox et al. (2003), challenge pupils' thinking through providing experiences which result in cognitive dissonance or conflict. The problem solving situations prompt pupils to try various approaches, in order to find the most appropriate solution, and the online role games develop collaboration strategies and communication skills.

Most of the reactions against computer-based learning stem from the "fear of the unknown", since autonomous learning is a relatively new practice in the field of education and its outcomes are often considered subversive. The digital environment may seem threatening, or even dangerous, to states which violate the right for individualized and holistic education and introduce inappropriate curricula that are compulsorily and uniformly applied to all students (Raptis \& Rapti, 2006). Undoubtedly, Information and Communication Technology (ICT) offers a great potential for critical thinking, autonomous learning and communication (Kolias, 1999; Komis, 2005). However, it must be made clear that the use of new technologies is not a panacea and that "in vivo" education cannot and should not be in any way replaced. It is, also, quite obvious that the improper or incorrect use of ICT and the production of software that does not meet quality criteria and standards can cause learning gaps in the recipient (Kossyvaki, 2003). Moreover, the rapid and unrestrained introduction of technology into educational life has already produced a new generation of "technological outcasts", in particular individuals who, due to their advanced age or because of deficiencies in learning experiences, have not come into contact with computers. These factors have led to an increase in educational inequalities (Bash, 2005; Hutton \& Giddens, 2001). Thus, the educators themselves, who often tend to reproduce the stereotypes of the traditional education they have received, may need to have special training, in order to apply this technology in a proper pedagogical manner in the classroom.

ICT constitutes an invaluable tool which can modify the human behaviour without being an "end in itself". In the light of the above, the aim of the present study is to investigate the application of ICT in Primary Schools on the island of Lesvos, Greece and to research educators' beliefs about the effects of ICT on teaching, learning and cognitive processes and on the development of critical thinking.

The present article unfolds part of the outcomes of a wider research that explores the application of ICT in (Greek) primary schools and its impact on teaching, learning and cognitive processes, as well as on pupils' behavioural adjustment, as elicited by primary school teachers and pupils' responds. The research outcomes presented here record teachers' views - the individuals who play a decisive role within the area of education and are responsible for the realization of the goals of the educational system - on the contribution of ICT to the development of pupils' critical thinking skills.

\section{Method}

\subsection{Participants}

The sample of the research consists of 118 teachers working in primary schools on the island of Lesvos, Greece. The selection of the sample was based on two criteria: a) the specific teachers have daily and extensive, direct contact with students and, thus, a holistic view of their students and the educational tools utilized during the teaching and learning processes, b) according to prior research findings, one of the major inhibiting factors to the successful introduction of information technology into education and to the application of any innovations in general, are the teachers themselves. For they feel more secure and confident when they apply traditional teaching methods, which are familiar to them from their own learning experiences as students (Somekh, 2000; Muntaz, 2000). 
The Northern Aegean was selected to be the research area for the following reasons: a) the Greek regional policy is rather general and inadequate, as it does not take under consideration the particularities and the needs of insular regions, despite some efforts during the last decades towards this direction (e.g. Integrated Mediterranean Programme (1986-1992), INTERREG, LEADER, etc); b) the Northern Aegean islands are the borders of the European Union, and c) there are socio-economic and educational inequalities, due to the insularity and the geographical discontinuity of the region.

A stratified sampling technique was used, in order to select the research sample (students and teachers) from a number of primary schools. Firstly, the selection of schools was based on specific criteria: geographical criteria, the population of pupils and teachers in each school, the instrumentality and type of school, e.g. morning classes only or all-day schools. The application of the stratified sampling technique ensured that the sample of respondents is satisfactorily representative, since sampling errors during the selection of schools were significantly reduced. During the second stage, a random sampling was applied within the selected schools in order to decide which teachers would participate in the research project.

The sample consists of 36 male (30.5\%) and 82 female $(69.5 \%)$ teachers. $25(21.2 \%)$ of them are below the age of 30 years old, $40(33.9 \%)$ are between the ages of 30 and $40,45(38.1 \%)$ are between the ages of 41 and 50 , and 8 $(6.8 \%)$ between the ages of 51 and 60. Only $24(19.96 \%)$ subjects possess postgraduate degrees, whilst the rest 94 (80.34\%) have no postgraduate qualifications. Finally, the $37.61 \%$ of the teachers declared that they had attended ICT training programmes in the past, while the $62.39 \%$ had never participated in such seminars.

\subsection{Instrument}

The data elicitation instrument is a questionnaire, specially devised for the present research. Its construction was based on a) previous researches found in the international bibliography (Jonassen, 2000; Rumpagaporn \& Darmawan, 2007; Vrasidas \& McIsaac, 2001; Vosniadou, 2006), b) the Greek curriculum for the subject of Information Technology, as being taught in primary schools, c) the directions and guidelines given by the Ministry of Education regarding the teaching of the specific subject (YPEPTH, 1998, 2002, 2003) and d) the researchers' experience in primary school education issues. In order to ensure the validity of the questionnaire, an attempt was made to base both the semantic, and the thematic content of the questions on the educational, psychological and sociological theories, as discussed in the preceding chapters. Special emphasis was, also, given on the semantic analysis, since there have been many debates recently on the degree to which factorial analyses and numerical correlations constitute psychological and sociological representations. Also, a questionnaire was distributed to thirty primary ICT teachers, who evaluated the scale's questions, based on a five-point scale (1=not relevant and $5=$ completely relevant), according to the relevance of the content with the application of ICT in primary schools. An analysis of the evaluation results (Mean=4.97) showed the validity and adequacy of the contents of the questionnaire. The reliability coefficient for the split-half test was found to be .90 and the internal consistency reliability coefficient .91 .

The questionnaire includes seven thematic sections of "closed-type" questions. The first section aims at the investigation of the applicability and usefulness of ICT in the educational system (teachers, students and schools). The second section refers to the role of the teacher in modern schools. The third section is comprised of questions that refer to the possession of basic skills in computer operation by students. The fourth section refers to factors that hinder the introduction of ICT into primary schools. The fifth section contains questions that explore teachers' knowledge of the educational legislation, and the directions described in newsletters circulating in the educational field, concerning educational practice and the introduction of ICT into schools. The sixth section investigates issues relevant to teachers' training in ICT. Finally, in the last section school is sociologically approached, and its role in modern society is examined. At the beginning of the questionnaire, a number of questions aim at eliciting information concerning the gender, the age, the specialization, the possession of post-graduate qualifications and the teaching experience of the teachers.

The answers to the questions are given through a four-point Likert scale, where $1=$ not at all and $4=a$ lot. This scale is used for all the questions, except those in the third and the fifth section, where answers are given in the dipole format of $1=$ no and $2=$ yes. Moreover, the answers to the questions in section 4 are given through a multiple choice format and the answers in section 7 via a three-point scale, where $1=$ disagree, $2=$ agree and $3=\mathrm{do}$ not know / will not answer.

\section{Results}

Teachers' opinions about the effect of ICT on the development of pupils' critical thinking are analyzed through thirteen (13) questions in the first two sections of the questionnaire, which refer to critical thinking skills. Firstly, percentage based analyses are provided along with a hierarchical classification of significance regarding the 
questions which relate to the development of critical thinking. These are followed by an analysis of statistically significant differences in relation to independent variables: the gender of the teachers, their post-graduate qualifications, their training in ICT, their age and the years of teaching experience.

According to the data analysis, a percentage of teachers, ranging from $65.20 \%$ to $93.91 \%$, believe - from a fair degree or to a large degree - that the use of ICT assists students to: realize their strengths and weaknesses, identify possible errors during problem-solving, develop new strategies that facilitate their educational goals, express ideas and opinions without the fear of possible negative evaluations, and to set their own pace during the learning process. The sample group also expressed the beliefs that ICT: provides opportunities for the application of collaborative teaching and individualized learning, assists in multi-thematic approaches towards an object of knowledge, allows multi-faceted representations of meanings and notions, and enhances pupils' active and autonomous involvement in the learning process. However, there is also a percentage of teachers, from $6.09 \%$ to $34.7 \%$, who do not favor the use of ICT, providing mostly "not at all" or "a little" as responses. The chi-square criterion was used to examine the variance in teachers' opinions and it was found that there was a statistically significant difference in opinions (table 1). As far as the contributions of ICT to the development of learners' critical thinking are concerned, $65.20 \%$ of the teachers believe "fairly" or "a lot" that the use of ICT enhances critical thinking, while $34.70 \%$ of the teachers state opposing opinions (table 1).

\section{[Table 1 about here]}

Accordingly, regarding the statement: "Greek schools cultivate the development of critical thinking in students", a small percentage of teachers, $6.17 \%$, responded negatively. In contrast $30.17 \%$ responded positively. However, over half of the teachers, $64.66 \%$, selected the "do not know / will not answer" response. The chi-square criterion was again used to examine the variance in teachers' opinions and it was established that a statistically significant difference existed (table 2).

\section{[Table 2 about here]}

In order to further evaluate teachers' responses, the multivariate analysis of variances with repeated measures was applied. The analysis showed a statistical significance: Hotelling's Trace, F $(11,107)=9.849, p=.000, \eta^{2}=.52$. The comparison for the primary function also showed statistical significance: $F(1,117)=114.86, \mathrm{p}<.001, \eta^{2}=.51$.

[Diagram 1 about here]

As depicted in Diagram 1, the mean scores are ranged in a hierarchically incremental order and the differences between them are statistically significant. According to teachers' responses, the multi-thematic approach towards an object of knowledge, the multi-faceted representations of meanings and notions, and the expression of ideas without the fear of a possible negative evaluation are the most significant effects of ICT on learning.

The second grouping, in hierarchically incremental order of importance, which seems to be supported to a large extent by the teachers, is that ICT supports individualized and inventive learning, contributes to the development of strategies for the successful accomplishment of learning goals, and promotes pupils' autonomy and active involvement in the learning process. The third grouping, in hierarchically incremental order of importance, includes opinions related to: the application of ICT for the identification of possible errors during problem-solving processes, the facilitation of collaborative learning, students' awareness of their strengths and weaknesses, and opinions regarding the impact on learning procedures regarding the individual pace of learning of each student. The last grouping in the hierarchical order is the belief that ICT contributes to the development of students' critical thinking.

No statistically significant differences were found, regarding the teachers opinions about research questions concerning critical thinking, regarding the variables of gender, age, and training in ICT. On the contrary, significant differences were established in the case of the possession of a second university degree or post-graduate qualifications (Table 3). The analysis of the data regarding the variable "post-graduate qualifications", in reference to the question: "Does the use of ICT lead to the development of learners' critical thinking?" was carried out using the Mann-Whitney Test, since the number of subjects in each group would not allow the deduction of reliable results.

\section{[Table 3 about here]}

The results of the analysis showed that subjects with post-graduate qualifications, as opposed to those without, had statistically significant negative opinions regarding the statements that ICT: a)gives students the opportunity to set and follow their own pace of learning, b)encourages the testing and free expression of ideas without the fear of possible negative evaluations, c)supports teachers when utilizing collaborative learning, d)creates opportunities for the utilization of a multi-thematic approach towards an object of knowledge, e)allows the presentation of multi-faceted representations of meanings and notions and f)enhances students' autonomy and active involvement in 
the learning process. It is quite obvious that post-graduate qualifications considerably influence and lead to significant differences in teachers' opinions regarding the effect of ICT use on the development of critical thinking.

\section{Discussion}

Durkheim (1956) emphatically expresses the significance of the distinct role that education plays in the formation of personality traits in young people, the need for maintenance of social cohesion and the pressures exercised on the new members for their "smooth" entry and integration into society. Thus, education aims to prepare citizens for entry into a society which, on general grounds, will be similar to the society that defined the aims and the practices of their education. Nowadays, we are educating a generation which will live in a drastically different environment; the rapid pace with which human knowledge is being developed often renders the information that students are receiving obsolete and deficient, even before they have completed their basic education (Castells, 1996; Kelly, 2006).

ICT contributes to the rapid changes in the social-political-economic structure of societal becoming and builds a new economy based on knowledge, upgrading at the same time the role of human potential. According to the aforementioned, the new model citizen is no longer an individual that merely assimilates defined knowledge and skills supplied by the educational system but, on the contrary, one that can collect information from a variety of sources, evaluate it and then act based on their own reasoning. Future citizens will be judged according to their ability to continuously absorb new knowledge in a constantly changing environment and the ability to proceed to the application of this knowledge. Modern schools must orient themselves towards the active involvement of students in the learning process through activities which aim at developing autonomy, discovery, motivation and the skills which are necessary for life-long learning (Papert, 1980; Raptis \& Rapti, 2006).

It is, thus, imperative for teachers to set clear goals and orient their teaching towards the preparation of citizens possessing the capacity for critical thinking, citizens that will be capable of responding to the rapid changes taking place in the global economy and society and to the technological advances that have been made over the past fifty years. Changes which necessitate that those citizens are capable of responding to the expectations of modern societies. (Bagakis, 2005; Matsaggouras, 2004; Mumtaz, 2000).

According to the research results, a significant number of teachers believe that the introduction of ICT into the educational curricula: helps students realize their strengths and weaknesses, indicates methods to develop new strategies in order to achieve learning goals and assists students to gain knowledge through active involvement and autonomous behavior. At the same time, the use of ICT facilitates teaching, providing opportunities to apply a variety of modern didactic techniques (collaborative teaching, individualized and inventive learning, multi-thematic approaches, etc.). Teachers believe that ICT allows for: a multi-thematic approach to an object of knowledge, multi-faceted representations of meaning, and the acquisition of knowledge without difficulty. The aforementioned are important since they reveal to the student that learning -as well as the didactic techniques that are elements of the educational praxis- has been modified and no longer follows the traditional model, where the teacher is defined merely as a "diffuser" of the knowledge found in invariable and unchanging books and teaching materials. Instead, the modern teacher should view and treat students as active participants in the process of knowledge acquisition and try to encourage them to voice their ideas, to think on real-life situations, relevant to their experiences (Hargreaves, 1999; Kossyvaki, 2003; Matsaggouras, 2004; Trilianos, 2000).

The effective teacher should possess knowledge and skills, which must be able to effectively utilize during the teaching process. He/she should assume the role of a mentor and be the intermediary between the computer, the software or information and the student, so that he/she can assist pupils and fortify their learning experiences. This last point is linked to the facts that: a) a portion of the teachers, ranging between $6.09 \%$ and $34.70 \%$, believe only "a little" or "not at all" with the abovementioned point and b) and that, on the hierarchical scale, teachers believe only to a small degree that ICT can enhance the development of critical thinking. An explanation for these results may be that the culture of the traditional school does not easily allow for the introduction of innovations and resists attempts for the remodeling or the improvement of the curricula and the school environment. Unfortunately, when new technologies started entering the classrooms, most of the teachers tried to use them-due to lack of training-as part of their traditional teaching methods, which only aimed at the transmission of knowledge (Raptis \& Rapti, 2006). This is the primary reason why many research reports did not show any positive outcomes from the utilization of technology in education. This preponderance towards neutral or negative findings, and the theoretical and impractical nature of training, regarding the introduction of ICT into education is also linked to the reality that teachers without post-graduate qualifications have a more positive attitude, compared to those with post-graduate qualifications, towards the beneficial contribution of ICT to the teaching and learning process and, more specifically, to the creation of conditions for the development of critical thinking. It should be noted that teachers' doubts about 
the positive impact of ICT on the development of critical thinking and learning in general, have an important effect on the generation of stereotypes and viewpoints that define the teaching practices and methodology (Kordaki, 2001; Kynigos \& Xenou, 2000; Politis, Roussos, Tsaousis \& Karamanis, 2000). Moreover, the majority of the teachers have not yet realized the orientation that education should have: the creation of autonomous citizens, capable of critical thought. The fact that over half of the teachers (64.66\%) avoided to answer the question "Is critical thinking developed within the educational system?" brings us face to face with an unfortunate reality. This fact necessitates the application of procedures that will bring about the sensitization, the training and the lifelong education of the teaching staff-procedures that differ drastically from those that were the practices until now (Darling-Hammond, 2000; Panitsidou \& Papastamatis, 2009). It is important for every educational system to invest in the training of the teaching staff in ICT, in the appropriate equipment of schools, and in the creation of a broad communication network between schools. What is more, the educational materials, which are going to be incorporated into the teaching and learning process, should aim at the creation of a student-cantered learning environment and the cross-thematic approach of knowledge, through active and participatory learning procedures.

\section{References}

Bagakis, G. (Ed.). (2005). Training and professional development of teacher. Athens: Metaihmio (in Greek).

Bash, L. (2005). Teaching and the globalization of knowledge. In D. Coulby, \& E. Zambeta (Eds.), World Yearbook of Education 2005: Globalisation and Nationalism in Education (pp. 175-189). London: Routledge.

Brunner, J. (1996). The culture of education. Cambridge, MA: Harvard University Press.

Castells, M. (1996). The rises of the networked society. Oxford: Blakcwell.

Cox, M., Abbott, C., Webb, M., Blakeley, B., Beauchamp, T., \& Rhodes, V. (2003). ICT and attainment: A review of the research literature, ICT in schools research and evaluation series no.17. Coventry/London: Becta/DfES

Crawford, K. (1996). Vygotskian approaches in human development in the information era. Educational Studies in Mathematics, 31, 43-62. doi: 10.1007/BF00143926, http://dx.doi.org/10.1007/BF00143926

Darling-Hammond, L. (2000). How teacher education matters. Journal of Teacher Education, 51(3), 166-173. doi: 10.1177/0022487100051003002, http://dx.doi.org/10.1177/0022487100051003002

Dawes, R.M. (1988) Rational choice in an uncertain world. Orlando, Fla: Harcourt Brace.

Durkheim, E. (1956). Education and Sociology (S. Fox, Trans.). New York: The Free Press.

Giavrimis, P., Papanis, E., \& Roumeliotou, M. (2009). Issues on sociology of education. Athens, Greece: Sideris (in Greek).

Griffin, P., \& Cole, M. (1984). Current activity for the future: The zoped. In B. Rogoff, \& J. V. Wertsch (Eds.), Children's learning in the zone of proximal development (pp. 45-64). San Francisco, CA: Jossey-Bass.

Hargreaves, D. (1999). The knowledge-creating school. British Journal of Educational Studies, 47(2), 122-144. doi:10.1111/1467-8527.00107, http://dx.doi.org/10.1111/1467-8527.00107

Hutton, W., \& Gidden, A. (Eds.). (2001). On The Edge. Living with global capitalism. London: Vintage.

Jonassen, D.H. (2000). Computers as Mindtools for Schools: Engaging Critical Thinking. Columbus, OH: Prentice-Hall.

Kahane, H. (1997). Logic and Contemporary Rhetoric ( $8^{\text {th }}$ ed). Belmont, Calif.: Wadsworth.

Kapsalis, A., \& Nima, E. (2002). Modern teaching. Thessaloniki, Greece: University of Thessaloniki Publishing (in Greek).

Kelly, P. (2006). What is teacher learning? A socio-cultural perspective. Oxford Review of Education, 32, 505-519. doi:10.1080/03054980600884227, http://dx.doi.org/10.1080/03054980600884227

Koliadis, Em. (1995). Theories of learning and educational practice. Athens, Greece: Self-published (in Greek).

Kolias, A. (1999). Computers in teaching and learning: A critical approach. Athens: Hellin (in Greek).

Komis, B. (2005). Introduction to teaching informatics. Athens: Kleidarithmos (in Greek).

Kordaki, M. (2001 November). Special characteristics of computer science effects on teaching and learning: Views of teachers. Paper presented at 8th Panhellenic Conference of Greek Computer Society. Nicosia, Cyprus.

Kossyvaki, F. (2003). Alternative education: Proposals for a transition from the education of the object to the education of the active subject. Thessaloniki: Gutenberg (in Greek). 
Kynigos, Ch., \& Xenou, N. (2000). New practices with new tools in the classroom: Trainers' training for the creation of untilisation societies of new technologies in the school. Paper presented at 2nd Conference with international Participation: ICT in Education. Patra Greece (p.p. 55-64). [Online] Available: http://www.etpe.gr/files/proceedings/uploads1/paper95.pdf (June 25, 2009).

Lee, K.T. (2002 December). Learning with ICT: The challenge of changing the way we teach. Proceedings of the ICCE, 2002 (772-776), Auckland, New Zealand.

Livingston, K., \& Condie, R. (2003). Evaluation of the SCHOLAR Programme. Final report for the Scottish Executive Education Department. Edinburgh: Scottish Executive.

Margolin, V. (1997). The struggle for utopia: Rodchenko, Lissitzky, Moholy-Nagy: 1917-1946. Chicago: The University of Chicago Press.

Matsaggouras, H. (2004). Teaching strategies: Critical thinking in teaching practice. Athens, Greece: Gutenberg (in Greek).

Mayer, R.E. (1992) Thinking, problem solving, cognition. New York: Freeman.

McMahon, G. (2009). Critical Thinking and ICT Integration in a Western Australian Secondary School. Educational Technology \& Society, 12 (4), 269-281

Mumtaz, S. (2000). Factors affecting teachers use of information and communications technology: a review of the literature. Journal of Information Technology for Teacher Education. 9(3), 319-341. doi: 10.1080/14759390000200096, http://dx.doi.org/10.1080/14759390000200096

Noss, R., \& Hoyles, C. (1996). Windows on mathematical meanings: Learning cultures \& computers. Dordrecht: Kluwer Academic Publishers.

OECD (1996). The knowledge-based economy. Paris: OECD Publications.

Panitsidou, E., \& Papastamatis, A. (2008 October). Learning organisations in education. Teacher training: Trends, criticism, suggestions. Paper presented at 3rd Hellenic Conference of the Drama Society of Education Science, Drama, Greece (in Greek).

Papert, S. (1980). Mindstorms: Children, computers, and powerful ideas. New York: Basic Books.

Papert, S. (1996). The connected family: Bridging the digital generation gap. Atlanta, GA: Longstreet Press.

Passey, D., Rogers, C., Machell, J. and McHugh, G., (2004), The Motivational effect of ICT on pupils. England: DfES/University of Lancaster.

Politis, P., Roussos, P., Tsaousis, G., \& Karamanis, M. (2000). Assessment of teachers' training within the project ODYSSEAS. In B. komis (Ed.), ICT in Education (p.p. 583-592). Athens: New Technology (in Greek).

Raptis, A., \& Rapti, A. (2006). Learning and teaching at the Information Age. Athens: Self-published (in Greek).

Rifkin, J. (1996). The end of work: The decline of global labor force and the down of the post-market-era. Athens, Greece: Nea Synora (in Greek).

Rumpagaporn, M., \& Darmawan, G. (2007). Students' critical thinking skills in a Thai ICT schools pilot project. International Education Journal, 8(2), 125-132. [Online] Available: http://ehlt.flinders.edu.au/education/iej/articles/v8n2/v8n2.pdf (September 12, 2009)

Somekh, B. (1998). Supporting information and communication technology innovations in higher education. Journal of Information Technology for Teacher Education, 7(1), 11-33. [Online] Available: http://citeseerx.ist.psu.edu/viewdoc/download?doi=10.1.1.15.1075\&rep=rep1\&type=pdf (September 23, 2009)

Torff, B. (2006). Expert teachers' beliefs about use of critical thinking activities with high and low-advantage learners. Teacher Education Quarterly, 33(2), 37-52. [Online] Available: http://www.teqjournal.org/backvols/2006/33_2/11 torff.pdf (October 09, 2009)

Trilianos, Th. (2000). The methodology of teaching. Athens, Greece: Tolidi (in Greek).

Trucano, M., (2005). Knowledge maps: ICTs in Education. Washington DC: InfoDev/WorldBank.

Tsui, L., (2002). Fostering critical thinking through effective pedagogy: Evidence from four institutional case studies. The Journal of Education, 73(6), 740-763. doi: 10.1353/jhe.2002.0056, http://dx.doi.org/10.1353/jhe.2002.0056

Vosniadou, St. (2006). Children, schools and computers: Prospects, problems and proposals for the more effective use of new technologies in the education. Athens: Gutenberg. 
Vrasidas, C., \& McIsaac, M. (2001). Integrating technology in teaching and teacher education: Implications for policy and curriculum reform. Educational Media International, 38(2/3), 127-132. doi: 10.1080/09523980110041944, http://dx.doi.org/10.1080/09523980110041944

Wertsch, J. V. (1984). The zone of proximal development: Some conceptual issues. New Directions for Child and Adolescent Development, 1984(23), 7-18. doi: 10.1002/cd.23219842303, http://dx.doi.org/10.1002/cd.23219842303

YPEPTH [Ministry of Education and Religious Affairs] (2002). ASPs. (Curriculums; APs in Greek) of Compulsory Education (Vols. A and B). Athens: Pedagogical Institute (in Greek).

YPEPTH. (2003). IIFSPSPS (Intra-thematic Integrated Framework of Studies Programmes; DEPPS in Greek). Athens: Pedagogical Institute (in Greek).

YPEPTH. (1998). IT at School: Its design and work. Athens: Pedagogical Institute (in Greek).

Table 1. Relative Frequencies and chi-square in regard to critical thinking skills.

\begin{tabular}{|c|c|c|c|c|c|}
\hline \multirow[b]{2}{*}{ Questions } & \multicolumn{4}{|c|}{ Percent } & \multirow[b]{2}{*}{$\chi^{2}(3)$} \\
\hline & Not at all & A little & Fairly & A lot & \\
\hline $\begin{array}{l}\text { Does the utilization of ICT during the lesson assist a student } \\
\text { in becoming aware of their strong and weak points? }\end{array}$ & 1.70 & 24.30 & 59.10 & 14.80 & $83.30^{*}$ \\
\hline $\begin{array}{l}\text { Does the utilization of ICT during the lesson help a student } \\
\text { to pinpoint mistakes in problem solving procedures? }\end{array}$ & 1.80 & 19.50 & 58.40 & 20.40 & $77.19 *$ \\
\hline $\begin{array}{l}\text { Does the utilization of ICT during the lesson lead a student } \\
\text { to develop new strategies in order to achieve learning goals? }\end{array}$ & .90 & 12.20 & 58.30 & 28.70 & $85.87^{*}$ \\
\hline $\begin{array}{l}\text { Does the utilization of ICT during the lesson give a student } \\
\text { the opportunity to set the rhythm and pace of their learning? }\end{array}$ & 7.00 & 21.70 & 51.30 & 20.00 & $48.44 *$ \\
\hline $\begin{array}{l}\text { Does the utilization of ICT during the lesson give a student } \\
\text { the opportunity to test out various versions of their opinion } \\
\text { and knowledge without the fear of being evaluated } \\
\text { negatively? }\end{array}$ & 1.70 & 8.60 & 44.80 & 44.80 & $74.07 *$ \\
\hline $\begin{array}{l}\text { Does the utilization of ICT accommodate teaching staff } \\
\text { when utilizing group teaching? }\end{array}$ & 6.09 & 21.74 & 46.96 & 25.22 & $39.12 *$ \\
\hline $\begin{array}{l}\text { Does the utilization of ICT grants the ability to utilize } \\
\text { multi-thematic approaches towards an object of knowledge? }\end{array}$ & 2.61 & 3.48 & 44.35 & 49.57 & $89.35^{*}$ \\
\hline $\begin{array}{l}\text { Does the utilization of ICT allow the presentation of } \\
\text { multi-faceted representations of meaning? }\end{array}$ & 2.63 & 5.26 & 46.49 & 45.61 & $81.02 *$ \\
\hline $\begin{array}{l}\text { Does the utilization of ICT accommodate teaching staff } \\
\text { when utilizing individual-to-individual and inventive } \\
\text { learning? }\end{array}$ & 1.80 & 7.00 & 58.80 & 32.50 & $93.93 *$ \\
\hline $\begin{array}{l}\text { Does the utilization of ICT accommodate teaching staff } \\
\text { when utilizing collaborative learning? }\end{array}$ & 6.10 & 25.20 & 40.00 & 28.70 & $27.43^{*}$ \\
\hline $\begin{array}{l}\text { Does the utilization of ICT increase students' active and } \\
\text { autonomous behavior? }\end{array}$ & 2.60 & 12.20 & 54.80 & 30.40 & 72.79 \\
\hline $\begin{array}{l}\text { Does the utilization of ICT lead to the development of } \\
\text { students' critical thinking? }\end{array}$ & 4.30 & 30.40 & 45.20 & 20.00 & $40.93 *$ \\
\hline
\end{tabular}


Table 2. Relative Frequencies and chi-square in regard to the question "Greek schools cultivate the development of critical thinking in students".

\begin{tabular}{llccccc}
\hline \multicolumn{1}{c}{ Question } & & Disagree & Agree & $\begin{array}{c}\text { Don't know/ } \\
\text { Won't answer }\end{array}$ & Total & $\chi^{2}(2)$ \\
$\begin{array}{l}\text { Greek schools cultivate the } \\
\text { development of critical thinking in }\end{array}$ & Frequency & 6 & 35 & 75 & 118 & \\
students & Percent & 5.17 & 30.17 & 64.66 & 100 & $62.086^{*}$ \\
\hline
\end{tabular}

Table 3. Mann-Whitney - U test Relative to the critical thinking skills in regard to the possession of post-graduate qualifications $(\mathrm{PQ})$

\begin{tabular}{|c|c|c|c|c|}
\hline Questions & PQ & MR & $\mathrm{U}$ & Z \\
\hline \multirow{2}{*}{$\begin{array}{l}\text { Does the utilization of ICT during the lesson assist a student in becoming } \\
\text { aware of their strong and weak points? }\end{array}$} & no & 58,81 & \multirow[t]{2}{*}{891.50} & \multirow[t]{2}{*}{-.98} \\
\hline & yes & 52,02 & & \\
\hline \multirow{2}{*}{$\begin{array}{l}\text { Does the utilization of ICT during the lesson help a student to pinpoint } \\
\text { mistakes in problem solving procedures? }\end{array}$} & no & 56,85 & \multirow[t]{2}{*}{924.00} & \multirow[t]{2}{*}{-.26} \\
\hline & yes & 55,00 & & \\
\hline \multirow{2}{*}{$\begin{array}{l}\text { Does the utilization of ICT during the lesson lead a student to develop } \\
\text { new strategies in order to achieve learning goals? }\end{array}$} & no & 59,34 & \multirow[t]{2}{*}{842.50} & \multirow[t]{2}{*}{-1.38} \\
\hline & yes & 49,80 & & \\
\hline \multirow{2}{*}{$\begin{array}{l}\text { Does the utilization of ICT during the lesson give a student the } \\
\text { opportunity to set the rhythm and pace of their learning? }\end{array}$} & no & 60,73 & \multirow[t]{2}{*}{714.50} & \multirow[t]{2}{*}{$-2.32 *$} \\
\hline & yes & 43,98 & & \\
\hline \multirow{2}{*}{$\begin{array}{l}\text { Does the utilization of ICT during the lesson give a student the } \\
\text { opportunity to test out various versions of their opinion and knowledge } \\
\text { without the fear of being evaluated negatively? }\end{array}$} & no & 61,11 & \multirow[t]{2}{*}{733.50} & \multirow[t]{2}{*}{$-2.27^{*}$} \\
\hline & yes & 44,84 & & \\
\hline \multirow{2}{*}{$\begin{array}{l}\text { Does the utilization of ICT accommodate teachers when utilizing group } \\
\text { teaching? }\end{array}$} & no & 61,10 & \multirow[t]{2}{*}{718.50} & \multirow[t]{2}{*}{$-2.49^{*}$} \\
\hline & yes & 43,24 & & \\
\hline \multirow{2}{*}{$\begin{array}{l}\text { Does the utilization of ICT grants the ability to utilize multi-thematic } \\
\text { approaches towards an object of knowledge? }\end{array}$} & no & 61,21 & \multirow[t]{2}{*}{708.50} & \multirow[t]{2}{*}{$-2.68^{*}$} \\
\hline & yes & 42,80 & & \\
\hline \multirow{2}{*}{$\begin{array}{l}\text { Does the utilization of ICT allow the presentation of multi-faceted } \\
\text { representations of meaning? }\end{array}$} & no & 60,04 & \multirow[t]{2}{*}{761.00} & \multirow[t]{2}{*}{$-2.18^{*}$} \\
\hline & yes & 45,09 & & \\
\hline \multirow{2}{*}{$\begin{array}{l}\text { Does the utilization of ICT accommodate teachers when utilizing } \\
\text { individual-to-individual and analytical learning? }\end{array}$} & no & 58,31 & \multirow[t]{2}{*}{917.50} & \multirow[t]{2}{*}{$-.96^{*}$} \\
\hline & yes & 51,89 & & \\
\hline \multirow{2}{*}{$\begin{array}{l}\text { Does the utilization of ICT accommodate teachers when utilizing } \\
\text { collaborative learning? }\end{array}$} & no & 59,77 & \multirow[t]{2}{*}{839.50} & \multirow[t]{2}{*}{-1.54} \\
\hline & yes & 48,50 & & \\
\hline \multirow{2}{*}{$\begin{array}{l}\text { Does the utilization of ICT increase students' active and autonomous } \\
\text { behavior? }\end{array}$} & no & 60,24 & \multirow[t]{2}{*}{797.00} & \multirow[t]{2}{*}{$-1.96^{*}$} \\
\hline & yes & 46,65 & & \\
\hline \multirow{2}{*}{$\begin{array}{l}\text { Does the utilization of ICT lead to the development of students' critical } \\
\text { thinking? }\end{array}$} & no & 57,76 & 1022.50 & -.18 \\
\hline & yes & 56,46 & & \\
\hline
\end{tabular}

Note: $* \mathrm{p}<.05 * * \mathrm{MR}=$ Mean Rank, U= Mann-Whitney U 


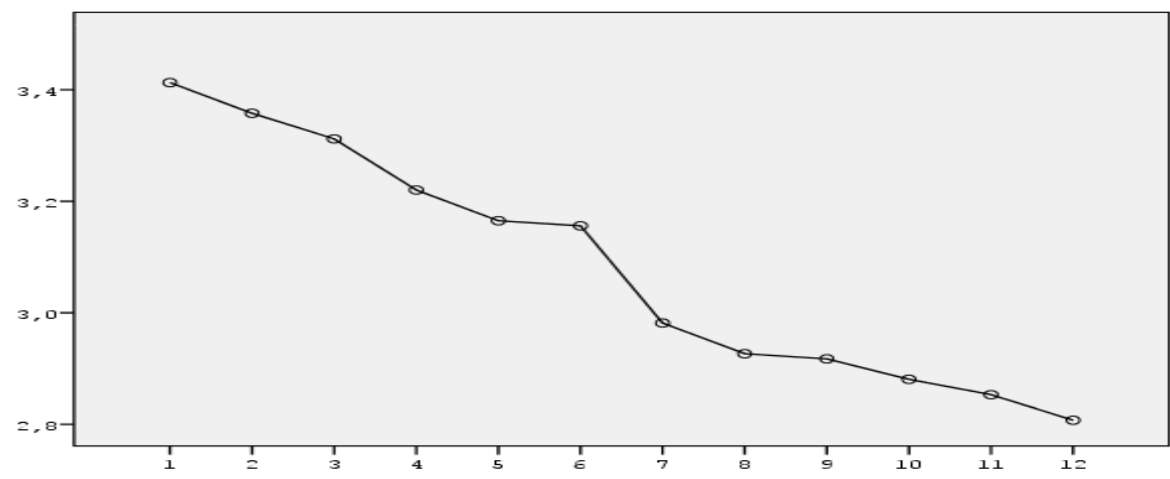

Diagram 1. Hierarchical ordering of the critical thinking skills

Note: 1. ICT grants the ability to utilize multi-thematic approaches towards an object of knowledge. 2. ICT allows the presentation of multi-faceted representations of meaning. 3. ICT gives a student the opportunity to test out various versions of their opinion and knowledge without the fear of being characterized negatively. 4. ICT accommodates teaching staff when utilizing individual-to-individual and inventive learning. 5. ICT assists a student to develop new strategies in order to achieve learning goals. 6. The utilization of ICT increases the active and autonomous behavior of students. 7. ICT helps a student to pinpoint mistakes in problem solving procedures. 8. ICT accommodates teaching staff when utilizing collaborative learning. 9. ICT accommodates teaching staff when utilizing group teaching. 10. The utilization of ICT assists a student in becoming aware of their strong and weak points. 11. The utilization of ICT gives a student the opportunity to set the rhythm and pace of their learning. 12 . ICT leads to the development of critical thinking in students. 